\title{
AVALIAÇÃO DA ATIVIDADE POZOLÂNICA DE MICROSSÍLICA CINZA DENSIFICADA E NÃO DENSIFICADA
}

\author{
M. A. S. ANJOS ${ }^{1 *}$, T. V. FONSECA ${ }^{2}$, L. K. M. MENDONÇA ${ }^{2}$ e C. M. PEDERNEIRAS ${ }^{2}$ \\ ${ }^{1}$ Intituto Federal de Educação, Ciência e Tecnologia do Rio Grande do Norte \\ ${ }^{2}$ Universidade Federal do Rio Grande do Norte \\ marcos.anjos@ifrn.edu.br*
}

Artigo submetido em março/2016 e aceito em setembro/2016

DOI: $10.15628 /$ holos.2016.2706

\section{RESUMO}

A possibilidade de adicionar um mineral aos materiais cimentícios a fim de obter melhores propriedades mecânicas e de durabilidade faz com que o estudo de adições com potencial pozolânico cresça cada vez mais. Este artigo consiste na investigação do índice de atividade pozolânica com cal e do índice de desempenho com cimento de microssílica cinza densificada e não densificada. Para tal, foram analisadas as resistências à compressão aos 7 dias da argamassa de cal e aos 28 dias da argamassa de cimento, comparando os resultados com os parâmetros mínimos de norma. Para caracterização dos materiais foram utilizados os ensaios de fluorescência de raio X (FRX) e difração de raio X (DRX). Com base no perfil amorfo e nas resistências mecânicas obtidas, verificou-se que ambas as microssílicas apresentaram atividade pozolânica.

PALAVRAS-CHAVE: Atividade pozolânica, microssílica cinza densificada, microssílica não densificada, DRX.

\section{POZZOLANICITY EVALUATION OF DENSIFIED MICROSILICA GRAY AND NOT DENSIFIED}

\begin{abstract}
The possibility of adding to a mineral cementitious materials in order to obtain better mechanical properties and durability makes the potential to study pozzolanic additions grow increasingly. This paper investigates the pozzolanic activity index with lime and the performance index with cement densified microsilica gray and not densified. Thus, we analyzed the resistance to
\end{abstract}

compression at 7 days of lime mortar and 28 days of cement mortar, comparing the results with the minimum standard parameters. For characterization of the materials used were X-ray fluorescence assays (XRF) and $X$-ray diffraction (XRD). Based on amorphous profile and the mechanical strength obtained, it was found that both microssílicas presented pozzolanic activity.

KEYWORDS: pozzolanicity, microsilica no densified. 


\section{INTRODUÇÃO}

As adições minerais são usualmente empregadas na produção de materiais cimentícios, as quais consistem em materiais silicosos finamente divididos. Os benefícios do uso das adições minerais incluem melhor resistência à fissuração térmica, aumento da resistência final e redução da permeabilidade, em razão do refinamento dos poros e fortalecimento da interface da matriz cimentícia, como também prolonga a vida útil por ter maior resistência ao ataque por sulfato (MEHTA \& MONTEIRO, 2008). As adições minerais se classificam como pozolânicas e/ou cimentantes e inertes.

Muller et al. (2015) caracteriza a hidratação do cimento como a dissolução de silicatos de cálcio com a formação de silicato de cálcio hidratado e hidróxido de cálcio. De acordo com a NBR 12653 (ABNT, 2014), os materiais pozolânicos reagem com hidróxido de cálcio para a formação de silicatos de cálcio hidratados adicional. Sua adição aos concretos, argamassas e pastas, comparada a um controle de referência, além das vantagens já expostas, também há um aumento na resistência à difusibilidade de íons cloreto, uma mitigação da reação álcali- agregado, um aumento da resistividade elétrica e uma redução no surgimento de eflorescências. Analisar a atividade pozolânica é avaliar a capacidade de determinado material de reagir com o hidróxido de cálcio em presença de água e formar compostos com propriedades cimentícias.

Dentre as adições pozolânicas, destaca-se a sílica ativa como o composto mais reativo, além de se comportar como o mais amorfo, é constituído por um percentual maior de sílica em sua composição química. A cinza volante, outra adição mineral bastante utilizada, apresenta consideravelmente menor atividade pozolânica quando comparada à sílica, o que pode ser observado no seu perfil de DRX, o qual demonstra um caráter muito mais cristalino, ou seja, menos reativo (Figura 1 ).

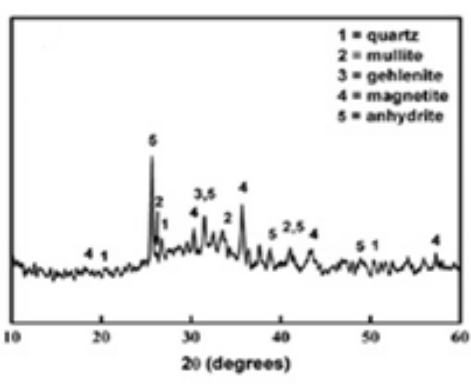

a)

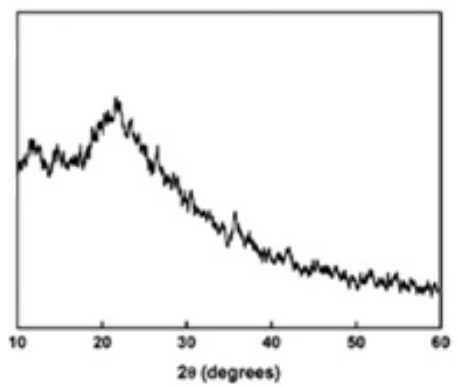

b)

Figura 1: DRX da cinza volante (a); e sílica ativa (b).

O mineral quartzo se denomina como sílica, que é um composto formado por oxigênio e silício, na forma de óxido de silício $\left(\mathrm{SiO}_{2}\right)$. Essa substância é constituída a partir da condensação do gás produzido na indústria siderúrgica. Nesse processo, o óxido de silício se resfria formando $\mathrm{SiO}_{2}$ amorfo ou vítreo.

A sílica ativa é um material pozolânico muito reativo devido a sua finura extrema e ao alto teor de óxido de silício amorfo. As vantagens do uso de sílica ativa consistem na alta resistência à compressão, no aumento da resistência à flexão e no módulo de elasticidade, e na baixa 
permeabilidade aumentando sua resistência aos ataques químicos. Nochaiya et al. (2010) conceitua a sílica como um material pozolânico proveniente do processo de fundição de silício e que consiste em partículas muito pequenas esféricas. A sílica ativa pode ser utilizada como uma substituição do cimento, a fim de reduzir o teor de cimento ou como uma adição para melhorar as propriedades de concreto (SIDDIQUE, 2011).

Quando a sílica ativa é adicionada à mistura ocorre uma mudança na interface entre os agregados e a pasta, pois ao invés dos vazios e do hidróxido de cálcio, evidencia-se formações compactas de $\mathrm{CSH}$, que é o produto de hidratação mais resistente da pasta endurecida. Esse fenômeno resulta em melhoras nas resistências mecânicas e na durabilidade. A reação da sílica favorece um aumento da resistência final da pasta e uma diminuição significativa da porosidade do sistema cimentício, provavelmente pela posterior conversão da sílica em CSH em sua reação pozolânica. De acordo com Prameetthaa et al. (2015), a sílica amorfa reage com produtos de hidratação e forma mais gel de CSH.

A sílica ativa por ser extremamente fina implica numa maior necessidade de água de amassamento na mistura, requerendo também o uso de aditivos redutores de água (MEHTA \& MONTEIRO, 2008). Esta característica pode comprometer as propriedades no estado fresco. As áreas específicas de algumas adições estão listadas na Tabela 1. O material mais pulverulento é identificado como a sílica ativa, a qual tem uma superfície específica muito elevada e atua como uma pozolana altamente reativa (CHANDRA \& BERNTSSON, 1996). Geralmente, a sílica é usada em quantidades pequenas em comparação com outros materiais pozolânicos.

Tabela 1: Área superficial específica dos materiais.

\begin{tabular}{c|c}
\hline Materiais & $\begin{array}{c}\text { Área específica } \\
\left(\mathbf{~ m}^{\mathbf{2}} \mathbf{~} \mathbf{k g}\right)\end{array}$ \\
\hline Sílica ativa & 15000 a 25000 \\
Metakaolin & 10000 a 25000 \\
Cinza volante & 250 a 600 \\
Cimento Portland & 300 a 400 \\
\hline
\end{tabular}

O efeito resultante do uso da sílica é a diminuição da trabalhabilidade. Essa redução precisa ser considerada, pois se não houver propósito de empregar um fator a/c muito alto, é necessário o uso de um aditivo plastificante ou superplastificante.

A sílica em seu estado bruto é classificada como não densificada (ROJAS et al., 1999). Esse estado do material não é muito recomendado para o uso em compósitos cimentícios devido a sua menor densidade quando comparado às outras formas de apresentação de sílica, ou seja, uma menor massa de material em um mesmo volume. Por ser um material leve, dificulta o seu manuseio e sua comercialização. A fim de melhorar essas propriedades de manipulação e transporte do material, ocorre o processamento da microssílica por métodos de densificação e compactação, de forma a aumentar sua densidade, originando a microssílica cinza densificada (YAJUN \& CAHYADI, 2003).

Segundo Rojas et al. (1999), a atividade pozolânica da sílica não densificada é maior nos primeiros dias, comparada à sílica densificada. Dessa forma, o calor de hidratação da sílica não densificada aumenta nas primeiras idades, enquanto para as sílicas ativas densificadas o calor de hidratação diminui. A sílica não densificada, portanto, aumenta consideravelmente a atividade pozolânica em função de sua maior facilidade de dispersão das partículas. 
As reduções de permeabilidade com sílica ativa são provenientes do refinamento e densificação da matriz e da redução do teor de $\mathrm{Ca}(\mathrm{OH})_{2}$ na zona interfacial da pasta de cimento com o agregado. Durante o processo de hidratação, a zona interfacial de transição é gradualmente densificada devido à reação pozolânica entre sílica ativa e hidróxido de cálcio (PACK et al, 2010).

Este trabalho visa avaliar o potencial pozolânico das adições minerais, a sílica flour, e as microssílicas cinza densificada e não densificada, a fim de comparar a pozolanicidade destes materiais. Além das melhorias das propriedades mecânicas e de durabilidade proporcionadas pelas adições minerais, o aproveitamento do resíduo da indústria siderúrgica (sílica ativa) implica na diminuição de danos ambientais, por promover uma destinação adequada. Assim como reduz o teor de cimento utilizado nas misturas, minimizando a emissão de $\mathrm{CO}_{2}$ proveniente das indústrias cimenteiras.

\section{METODOLOGIA}

\subsection{Materiais}

Esta pesquisa consiste no estudo de pastas e argamassas preparadas com cimento ou cal, e adições minerais como integrantes da parte ativa, e como parte inerte areia normal, obtida em conformidade com a NBR 7214 (ABNT, 2012). O cimento utilizado foi do tipo CP II F - 32 e a cal utilizada foi do tipo $\mathrm{CH}$ I, cujas caracterizações químicas podem ser vistas na Tabela 2.

Tabela 2: Composição química do cimento e da cal.

\begin{tabular}{c|c|c}
\hline $\begin{array}{c}\text { Composição } \\
\text { química }\end{array}$ & $\begin{array}{c}\text { Cimento CP II F } \\
-32 \text { (\%) }\end{array}$ & Cal CH I (\%) \\
\hline $\mathrm{Al}_{2} \mathrm{O}_{3}$ & 4,41 & 0,40 \\
$\mathrm{SiO}_{2}$ & 14,71 & 1,30 \\
$\mathrm{~K}_{2} \mathrm{O}$ & 1,26 & 0,39 \\
$\mathrm{CaO}$ & 68,68 & 97,29 \\
$\mathrm{Fe}_{2} \mathrm{O}_{3}$ & 2,35 & 0,29 \\
$\mathrm{MgO}$ & 2,70 & 0,20 \\
$\mathrm{SrO}^{2}$ & 0,05 & 0,04 \\
$\mathrm{ZrO}_{2}$ & 0,02 & - \\
$\mathrm{SnO}_{2}$ & - & 0,01 \\
$\mathrm{SO}_{3}$ & 5,48 & - \\
$\mathrm{Cl}$ & - & 0,03 \\
$\mathrm{TiO}_{2}$ & 0,33 & - \\
$\mathrm{ZnO}^{\mathrm{Na}_{2} \mathrm{O}}$ & 0,04 & - \\
\hline
\end{tabular}

Foram utilizadas três adições minerais para efeito de comparação, uma microssílica cinza não densificada e uma microssílica cinza densificada como adições pozolânicas, e a sílica flour como material apenas de preenchimento. As composições químicas desses materiais são mostradas na Tabela 3. 
Tabela 3: Composição química da microssílica cinza não densificada, microssílica cinza densificada e sílica flour.

\begin{tabular}{c|c|c|c}
\hline $\begin{array}{c}\text { Composição } \\
\text { química }\end{array}$ & $\begin{array}{c}\text { Microssílica } \\
\text { cinza não } \\
\text { densificada (\%) }\end{array}$ & $\begin{array}{c}\text { Microssílica } \\
\text { cinza densificada } \\
\text { (\%) }\end{array}$ & Sílica flour (\%) \\
\hline $\mathrm{Al}_{2} \mathrm{O}_{3}$ & 0,53 & 0,88 & 2,29 \\
$\mathrm{SiO}_{2}$ & 97,04 & 96,51 & 94,55 \\
$\mathrm{~K}_{2} \mathrm{O}$ & 1,22 & 0,84 & 0,09 \\
$\mathrm{CaO}$ & 0,14 & 0,35 & 1,40 \\
$\mathrm{Fe}_{2} \mathrm{O}_{3}$ & 0,05 & 0,08 & 1,66 \\
$\mathrm{MgO}$ & 0,30 & 0,60 & - \\
$\mathrm{PbO}_{\mathrm{SnO}}$ & 0,01 & - & - \\
$\mathrm{SO}_{3}$ & 0,04 & - & - \\
$\mathrm{Cl}$ & 0,11 & 0,16 & - \\
$\mathrm{MnO}$ & 0,35 & - & - \\
$\mathrm{Na}_{2} \mathrm{O}$ & - & 0,35 & - \\
\hline
\end{tabular}

\subsection{Preparação das amostras e cura}

Para se avaliar o índice de atividade pozolânica (IAP) com a cal, foram feitas três argamassas, denominadas de Arg. Cal P1 com a microssílica cinza não densificada, Arg. Cal P2 com a microssílica cinza densificada e Arg. Cal P3 com a sílica flour. Para cada argamassa foram moldados três corpos de prova cilíndricos de $50 \mathrm{~mm}$ de diâmetro por $100 \mathrm{~mm}$ de altura.

O proporcionamento dos materiais é dado pela NBR 5751 (ABNT, 2012), que especifica as quantidades em massa de cal e de areia normal, e sugere que a quantidade de material pozolânico seja o dobro do volume de cal, levando-se em consideração as densidades de ambos os materiais, conforme Equação (1). Os valores das massas específicas do material pozolânico e da cal hidratada, determinados de acordo com a NM 23 (ABNT, 2001), são respectivamente $\delta_{\mathrm{poz}}$ e $\delta_{\text {cal. }}$. As massas específicas encontradas estão demonstradas na Tabela 4 e a quantidade em massa de cada material por traço de argamassa na Tabela 5.

$$
\mathrm{m}_{\mathrm{poz}}=2 \times \frac{\delta_{\text {poz }}}{\delta_{c a l}} \times 104, \mathrm{em} \operatorname{gramas}(\mathrm{g})
$$

Tabela 4: Massa específica dos materiais no estado anidro.

\begin{tabular}{c|c}
\hline Materiais & $\begin{array}{c}\text { Massa específica } \\
\left(\mathbf{g} / \mathbf{c m}^{\mathbf{3}}\right)\end{array}$ \\
\hline Cal & 2,34 \\
Sílica Flour & 2,66 \\
Microssílica não densificada & 2,14 \\
Microssílica densificada & 2,06 \\
\hline
\end{tabular}

A argamassa foi preparada em um misturador mecânico, sendo incialmente adicionada uma quantidade mínima de água à mistura anidra de adição mineral e cal, para a homogeneização. Na sequência, foi verificada a consistência pelo flow table e esse procedimento foi repetido com adição gradativa da água. A quantidade de água usada para cada mistura foi correspondente a um índice de consistência de $(225 \pm 5) \mathrm{mm}$. 
Tabela 5: Quantidade dos materiais nas argamassas de cal P1, P2 e P3 para avaliação do IAP.

\begin{tabular}{c|c|c}
\hline Traço & Material & Quantidade (g) \\
\hline \multirow{4}{*}{ Arg. Cal P1 } & Hidróxido de cálcio (cal) & 104,0 \\
\cline { 2 - 3 } & Areia normal & 234,0 \\
\cline { 2 - 3 } & Microssílica cinza não densificada & 190,2 \\
\cline { 2 - 3 } & Água 0,05 & 245,0 \\
\hline \multirow{4}{*}{ Arg. Cal P2 } & Hidróxido de cálcio (cal) & 104,0 \\
\cline { 2 - 3 } & Microssílica cinza densificada & 234,0 \\
\cline { 2 - 3 } & Água & 183,1 \\
\hline \multirow{4}{*}{ Arg. Cal P3 } & Hidróxido de cálcio (cal) & 332,0 \\
\cline { 2 - 3 } & Areia normal & 104,0 \\
\cline { 2 - 3 } & Sílica Flour & 234,0 \\
\cline { 2 - 3 } & Água & 236,4 \\
\cline { 2 - 3 } & & 198,0 \\
\hline
\end{tabular}

A cura dos corpos de prova de argamassa com cal foi realizada no próprio molde, sendo feito um encamisamento na parte superior com material látex e um envolvimento com filme plástico transparente. Durante as primeiras 24 horas, os corpos de prova foram mantidos a temperatura de $(23 \pm 2)^{\circ} \mathrm{C}$ em um recipiente com água envolvido com filme plástico transparente. Durante as 144 horas posteriores, os corpos de prova foram mantidos em cura úmida aquecida a temperatura de $55^{\circ} \mathrm{C}$ em estufa.

Tabela 6: Quantidade dos materiais nas argamassas de cimento P1, P2, P3 e Ref para avaliação do IDC.

\begin{tabular}{c|c|c}
\hline Traço & Material & Quantidade (g) \\
\hline \multirow{4}{*}{ Arg. Cim P1 } & Cimento CP II-F-32 & 234,0 \\
\cline { 2 - 3 } & Areia normal & 936,0 \\
\cline { 2 - 3 } & Microssílica cinza não densificada & 78,0 \\
\cline { 2 - 3 } & Água & 150,0 \\
\cline { 2 - 3 } & Cimento CP II-F-32 & 234,0 \\
\cline { 2 - 3 } & Microssílica cinza densificada & 936,0 \\
\cline { 2 - 3 } & Água & 78,0 \\
\cline { 2 - 3 } & Cimento CP II-F-32 & 150,0 \\
\hline \multirow{4}{*}{ Arg. Cim P3 } & Areia normal & 934,0 \\
\cline { 2 - 3 } & Sílica Flour & 78,0 \\
\cline { 2 - 3 } & Água & 150,0 \\
\hline \multirow{3}{*}{ Arg. Ref } & Cimento CP II-F-32 & 312,0 \\
\cline { 2 - 3 } & Areia normal & 936,0 \\
\cline { 2 - 3 } & Água & 150,0 \\
\hline
\end{tabular}

Para avaliar a atividade pozolânica utilizando o cimento, é necessário determinar o índice


na NBR 5752 (ABNT, 2014). Foram formuladas três argamassas, denominadas de Arg. Cim P1, a argamassa com a microssílica cinza não densificada, Arg. Cim P2, a argamassa com a microssílica cinza densificada, Arg. Cim P3, a argamassa com sílica flour e Arg. Ref, a argamassa sem adição. Para cada argamassa foram moldados três corpos de prova cilíndricos de $50 \mathrm{~mm}$ de diâmetro por 
$100 \mathrm{~mm}$ de altura. Todas as quantidades são determinadas na norma, inclusive a quantidade de água. Na Tabela 6 estão apresentadas as quantidades de cada material.

Para os corpos de prova com argamassa de cimento, a cura nas primeiras 24 horas também foi feita nos moldes com proteção na parte superior. Após esse período, os corpos de prova foram desmoldados e imersos em um reservatório com água saturada de cal, até o período de 28 dias.

\subsection{Difração de raios $X$}

As amostras foram caracterizadas por difração de raios $X$ num equipamento Shimadzu XRD 6000 , submetidas às seguintes condições de análise: $40 \mathrm{kV}$ e $30 \mathrm{~mA}$, velocidade 1,5 grau/min, faixa de varredura $(2 \theta)$ de 5 a $70^{\circ}$, passo de varredura $0,02^{\circ}$ e tempo por passo $1 \mathrm{~s}$. Foram analisados a microssílica cinza não densificada, a microssílica cinza densificada, a sílica flour, a cal e o cimento CP II-F-32 no estado anidro, além das pastas de cal no estado endurecido. Todo o material para ensaio foi previamente destorroado com o auxílio de um almofariz de porcelana e passado pela peneira $200(0,075 \mathrm{~mm})$.

\subsection{Resistência à compressão}

Avaliou-se a resistência à compressão dos corpos de prova das argamassas com cal aos 7 dias. Os corpos de prova das argamassas com cimento foram avaliados aos 28 dias. Todos os corpos de prova foram secos ao ar e capeados com enxofre. $O$ ensaio foi realizado em uma prensa universal com carga de compressão a velocidade de 0,25 MPa/s.

$O$ índice de atividade pozolânica com a cal é atingido quando a resistência à compressão do material é maior ou igual a 6,0 Mpa aos 7 dias, de acordo com a NBR 12653 (ABNT, 2014). 0 índice de desempenho com o cimento é definido pela razão entre a média das resistências dos corpos de prova moldados com cimento e adição mineral ( $f(B)$ e a média das resistências dos corpos de prova moldados apenas com cimento (fCA). De acordo com a NBR 5752 (ABNT, 2014), essa relação tem que ser maior do que $90 \%$, conforme Equação (2).

$$
\mathrm{I}_{\text {cimento }}=\frac{f c B}{f c A} \times 100
$$

\section{RESULTADOS E DISCUSSÕES}

A sílica flour, a microssílica cinza densificada e não densificada foram avaliadas quanto ao seu potencial pozolânico. A composição química determinada pela fluorescência de raio $X$, descrita na Tabela 3, indica um elevado teor de sílica para todas as amostras. A microssílica não densificada contém $97,04 \%$ de $\mathrm{SiO}_{2}$, a microssílica densificada contém $96,51 \%$ e a sílica fluor é constiuída por 94,55\%, o que pode representar uma provável atividade pozolânica.

Com a análise das difrações de raio $X$ das amostras no estado anidro, pode-se verificar nestes difratogramas que as microssílicas densificada e não densificada se apresentam amorfas, sem picos característicos, o que pode indicar uma certa atividade pozolânica (Figuras 2 e 3). Já a sílica flour exibe alguns picos cristalinos de $\mathrm{SiO}_{2}$, o que pode prejudicar a pozolanicidade do material (Figura 4). 


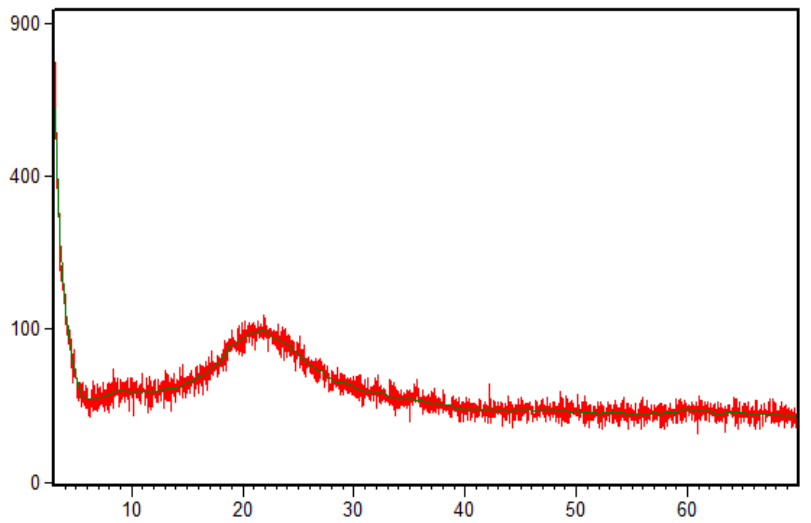

Figura 2: DRX da microssílica cinza densificada (P2) no estado anidro.

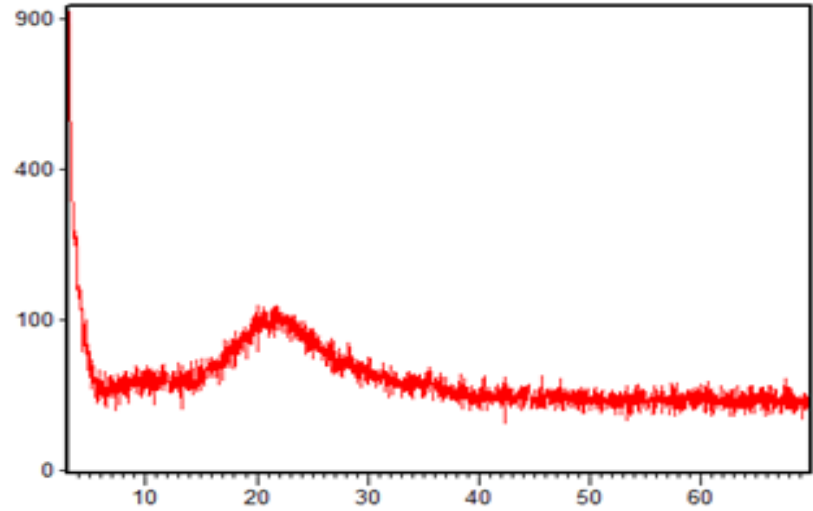

Figura 3: DRX da microssílica não densificada (P1) no estado anidro.

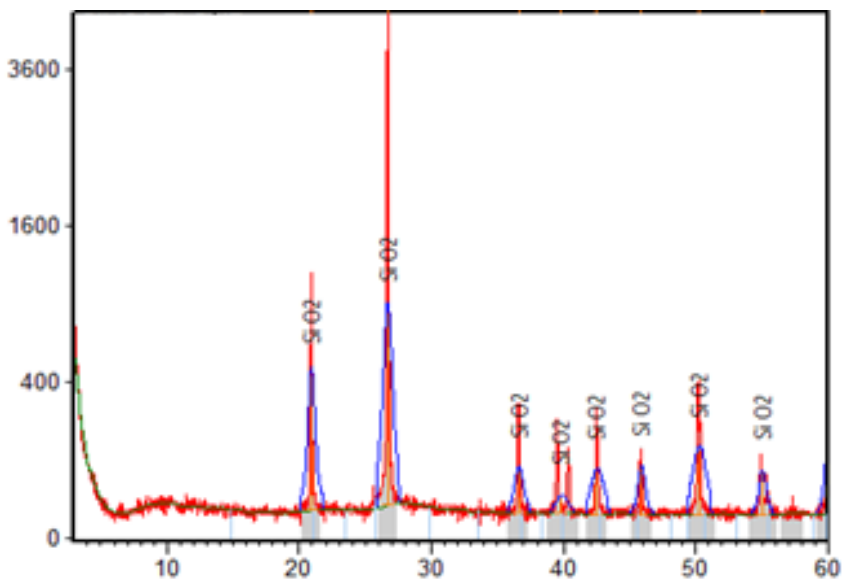

Figura 4: DRX da sílica flour (P3) no estado anidro.

No difratograma da cal hidratada no estado anidro (Figura 5), verifica-se picos cristalinos de portlandita $\left(\mathrm{Ca}(\mathrm{OH})_{2}\right)$, e pequenos picos de calcita $\left(\mathrm{CaCO}_{3}\right)$, o que pode ser corroborado na análise de Anjos et al. (2012). A presença de hidróxido de cálcio livre na cal proporciona as reações pozolânicas $\left(\mathrm{Ca}(\mathrm{OH})_{2}+\mathrm{SiO}_{2} \rightarrow \mathrm{CSH}\right)$. 


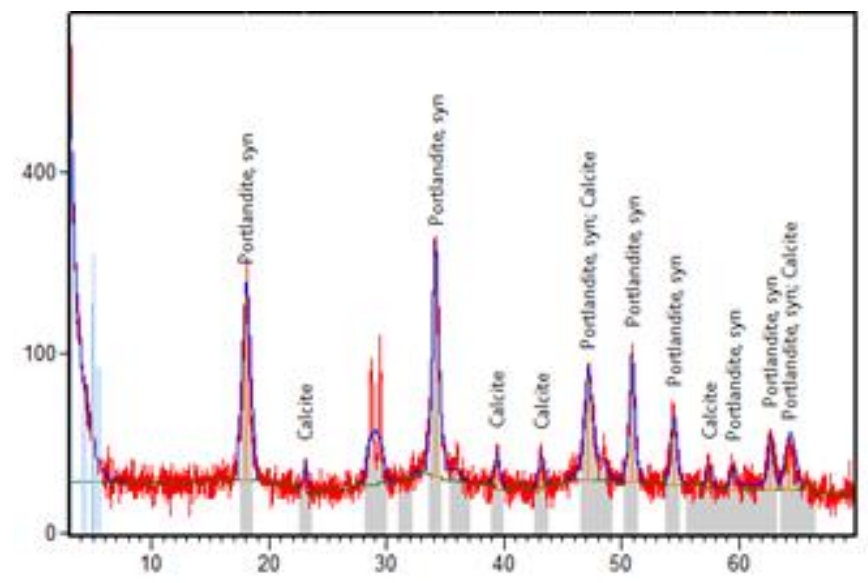

Figura 5: DRX da cal hidratada no estado anidro.

No DRX das amostras com cal e adição de microssílica densificada e não densificada pode ser verificada a ausência de picos de portlandita, o que indica o seu provável consumo pela reação com o dióxido de silício (encontrado na microssílica) na formação do $\mathrm{CSH}$, silicato de cálcio hidratado (Figura 6 e 7).

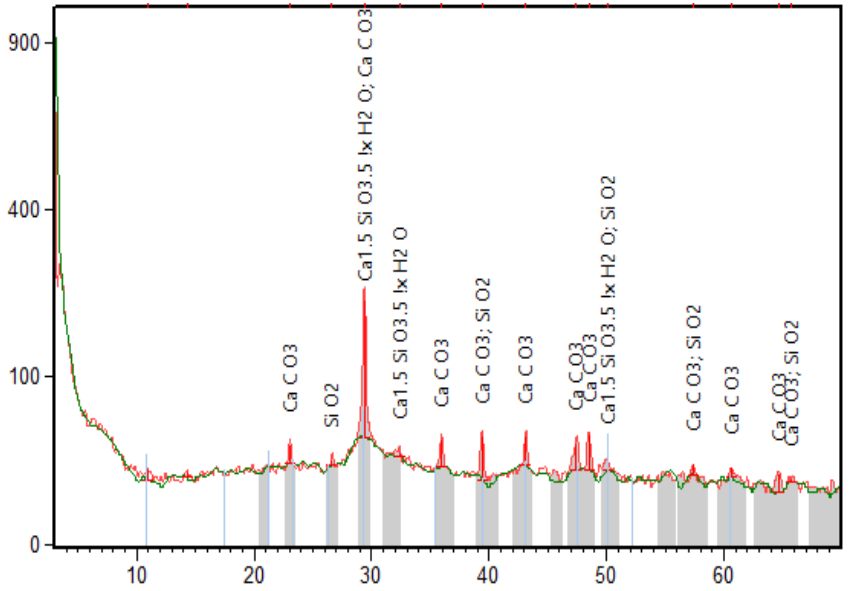

Figura 6: DRX da pasta de cal com adição de microssílica cinza densificada.

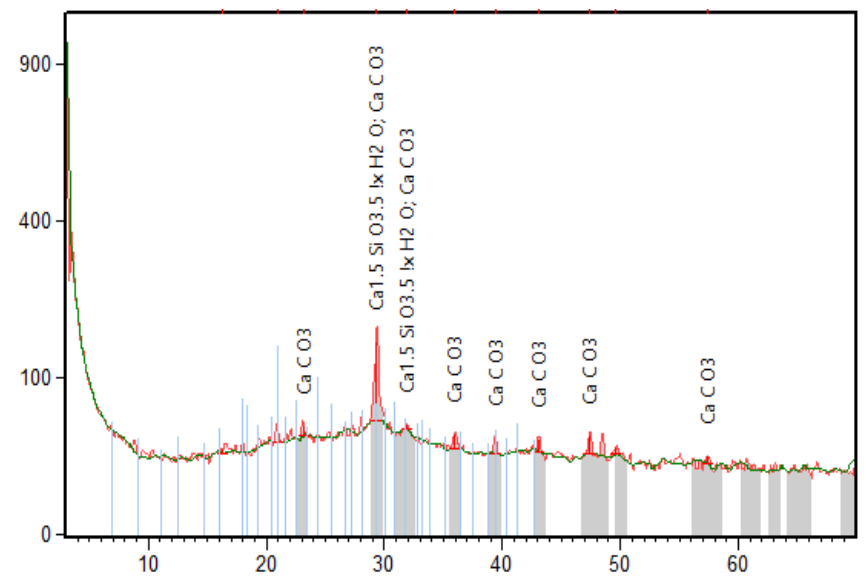

Figura 7: DRX da pasta de cal com adição de microssílica não densificada.

No DRX da pasta de cal com adição de sílica flour (Figura 8), verificam-se picos de quartzo $\left(\mathrm{SiO}_{2}\right)$, portlandita $\left(\mathrm{Ca}(\mathrm{OH})_{2}\right)$ e calcita $\left(\mathrm{CaCO}_{3}\right)$. Assim, indica a não formação de silicato de cálcio 
hidratado, o principal produto da reação pozolânica, o que corrobora com o seu perfil cristalino não reativo observado na Figura 4.

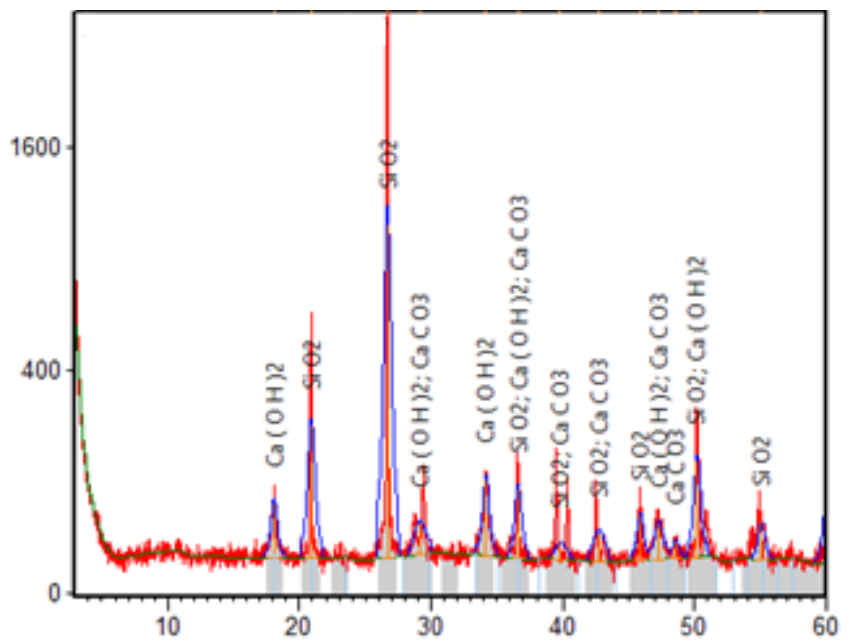

Figura 8: DRX da pasta de cal com adição de sílica flour.

As resistências das argamassas preparadas com cal, conforme mostrado na Tabela 7, indicam o índice de atividade pozolânica (IAP) do material. Nas amostras com a adição de sílica flour, microssílica densificada e não densificada foram realizados ensaios de resistência à compressão axial, aos setes dias da moldagem.

Os resultados da argamassa de cal com adição de sílica flour apresentaram valores inferiores ao parâmentro mínimo de norma, enquanto as argamassas de cal com adição de microssílica densificada e não densificada apresentaram valores superiores para materiais pozolânicos, o que corrobora os resultados apresentados no DRX das pastas de cal e adições minerais com relação à reatividade desses materiais.

Tabela 7: Resultados do ensaio de resistência à compressão das argamassas de cal.

\begin{tabular}{c|c|c|c|c}
\hline \multirow{2}{*}{ Argamassa } & \multicolumn{4}{|c}{ Resistência à compressão (MPa) } \\
\cline { 2 - 5 } & CP 1 & CP 2 & CP 3 & Média \\
\hline Cal + Microssílica Não Densificada (P1) & 8,86 & 8,57 & 9,67 & 9,03 \\
\hline Cal + Microssílica Densificada (P2) & 6,73 & 7,29 & 7,03 & 7,02 \\
\hline Cal + Sílica Flour (P3) & 0,26 & 0,05 & - & 0,10 \\
\hline
\end{tabular}

As argamassas preparadas com cimento e adições apontam o índice de desempenho com cimento Portland. As amostras foram rompidas pelo ensaio de resistência à compressão aos 28 dias. Os resultados obtidos, conforme Tabela 8 , demonstram a possível atividade pozolânica da microssílica densificada e da microssílica não densificada, uma vez que o índice de desempenho com o cimento foi superior aos $90 \%$ determinado em norma.

A argamassa com a adição de sílica flour obteve uma relação entre sua resistência e a da argamassa de referência muito baixa, como já era de se esperar devido a sua baixa reatividade, apresentando-se assim, como um material inerte, com o objetivo de preenchimento. 
Tabela 8: Resultados do ensaio de resistência à compressão das argamassas de cimento.

\begin{tabular}{c|c|c|c|c}
\hline \multirow{2}{*}{ Argamassa } & \multicolumn{3}{|c|}{ Resistência à compressão (MPa) } & \multirow{2}{*}{ IDC } \\
\cline { 2 - 4 } & CP 1 & CP 2 & Média & \\
\hline Cimento (referência) & 19,90 & 21,20 & 20,55 & - \\
\hline Cimento + Microssílica Não Densificada (P1) & 21,96 & 25,68 & 23,82 & \multirow{2}{*}{$115,91 \%$} \\
\hline Cimento + Microssílica Densificada (P2) & 25,89 & 29,71 & 27,80 & \multirow{2}{*}{$135,28 \%$} \\
\hline Cimento + Sílica Flour (P3) & 7,18 & 8,00 & 7,59 & $36,93 \%$ \\
\hline
\end{tabular}

\section{CONCLUSÃO}

As microssílicas cinzas não densificada e densificada caracterizam-se como adições pozolânicas bastante reativas. Os resultados no estado anidro justificam essa reatividade, pelo seu estado amorfo no DRX e pela sua composição química ser quase toda composta por sílica. Já a adição de sílica flour comporta-se como um material não reativo, exercendo apenas função de empacotamento dos grãos, uma vez que apresenta picos cristalinos no seu DRX, apesar do alto teor de sílica na sua composição química.

Os DRX's das pastas de cal com as microssílicas confirmam a pozolanicidade dos materiais devido ao consumo total da portlandita pelas reações pozolânicas existentes e pelo surgimento de picos de CSH. Diferentemente do que ocorre com a sílica flour, cujo DRX da pasta apresenta picos de portlandita e ausência de CSH.

Os resultados obtidos no estado endurecido demonstram que ambas as microssílicas atingem os parâmetros mínimos para o índice de desempenho com a cal e para o índice de desempenho com o cimento.

As adições minerais costumam ter um efeito retardador sobre a resistência nas primeiras idades. Entretanto, a capacidade da adição mineral reagir com o hidróxido de cálcio e de formar silicato de cálcio hidratado adicional pode levar a uma redução significativa na porosidade da matriz e na zona de transição, o que influencia diretamente na estanqueidade e, consequentemente, aumenta a durabilidade.

\section{REFERÊNCIAS BIBLIOGRÁFICAS}

1. ABNT - ASSOCIAÇÃO BRASILEIRA DE NORMAS TÉCNICAS. Areia normal para ensaio de cimento - Especificação. NBR 7214/2012. Rio de Janeiro, 2012. 4p.

2. ABNT - ASSOCIAÇÃO BRASILEIRA DE NORMAS TÉCNICAS. Cimento Portland e outros materiais em pó - Determinação da massa específica. NM 23/2001. Rio de Janeiro, 2001. 5p.

3. ABNT - ASSOCIAÇÃO BRASILEIRA DE NORMAS TÉCNICAS. Materiais pozolânicos Determinação da atividade pozolânica - Índice de atividade pozolânica com cal - Método de ensaio. NBR 5751/2012. Rio de Janeiro, 2012. 4p.

4. ABNT - ASSOCIAÇÃO BRASILEIRA DE NORMAS TÉCNICAS. Materiais pozolânicos Determinação do índice de desempenho com cimento Portland aos 28 dias. NBR 5752/2014. Rio de Janeiro, 2014. 4p. 
5. ABNT - ASSOCIAÇÃO BRASILEIRA DE NORMAS TÉCNICAS. Materiais pozolânicos - Requisitos. NBR 12653/2014. Rio de Janeiro, 2014. 6p.

6. ANJOS, M. A. S. et al. "Avaliação da hidratação de pastas cimentícias com elevados teores de adições minerais", Revista engenharia civil - Uminho Número 44, 2012, 18p.

7. CHANDRA, S.; BERNTSSON, L. "Use of silica fume in concrete", Waste Materials Used in Concrete Manufacturing, 1996, 112p.

8. MEHTA, P. K.; MONTEIRO, P. J. M. Concreto: microestrutura, propriedades e materiais. Ibracon, 2008, 674p.

9. MULLER et al. "Influence of silica fume on the microstructure of cement pastes: New insights from 1H NMR relaxometry", Cement and Concrete Research, 2015, 10p.

10. NOCHAIYA, T. et al. "Utilization of fly ash with silica fume and properties of Portland cement fly ash - silica fume concrete", Fuel, 2010, 7p.

11. PACK, S. et al. "Prediction of time dependent chloride transport in concrete structures exposed to a marine environment", Cement and Concrete Research, 2010, 11p.

12. PRAMEETTHAA, J. et al. "Investigation on micronized biomass silica as a sustainable material", Cement \& Concrete Composites, 2015, 9p.

13. ROJAS, M. I. S. et al. "Influence of the microsilica state on pozzolanic reaction rate", Cement and Concrete Research, 1999, $5 p$.

14. SIDDIQUE, R. "Utilization of silica fume in concrete: Review of hardened properties", Resources, Conservation and Recycling, 2011, 10p.

15. YAJUN, J.; CAHYADI, J.H. "Effects of densified silica fume on microstructure and compressive strength of blended cement pastes". Cement and Concrete Research, 2003, 6p. 